\title{
打放しコンクリートに生じた表面気泡、ひび割れ、コールドジョイントおよび 污れの外観が許容される限界に関する検討 \\ A CONSIDERATION ON ACCEPTABLE LIMITS OF APPEARANCE OF BUG-HOLES, CRACKS, COLD JOINTS AND STAINING ON EXPOSED CONCRETE
}

陶 山裕 樹*1, 高 巣 幸二*2, 小山田 英弘*2

\section{Hiroki SUYAMA, Koji TAKASU and Hidehiro KOYAMADA}

\begin{abstract}
We conducted questionnaire surveys on evaluation of surface defects in concrete specimens and reinforced concrete buildings. The questionnaire responses were statistically analyzed to identify and calculate the odds ratios of factors influencing defect evaluations. Based on these results, we investigated (1) the acceptable limits of bug-hole area ratio, crack width, and standard deviation of lightness — defined as the level at which half of evaluators are expected to accept—and (2) the psychological acceptability of the appearance of cracks with different widths and, particularly, a crack width of $3 \mathrm{~mm}$.
\end{abstract}

Keywords : exposed concrete, appearance, bug-holes, crack width, coldjoint, logistic regression analysis 打放しコンクリート, 外観, 表面気泡, ひび割れ幅, コールドジョイント, ロジスティック回帰分析

\section{1. はじめに}

打放しコンクリートには、強度、耐久性および施工性が求められ る一方、仕上げ材料として外観 (appearance) の良さが求められる。 コンクリートの外観は、一般的に「白い方が好まれる」、「表面気泡、 砂すじ、打重数およびひび副れといった不具合は嫌厭される」な どと説明される。しかしながら、コンクリートの外観に関する既往 の知見は、現場の経験則を根拠としたものが殆どであり、その多く が定性的な表現にとどまる。したがって、コンクリートの外観に関 する定量的な管理基準（たとえば、心理的に許容される外観の限界 など）は、ひび割れ幅を除き、殆ど規定されていない。効率的かつ 経済的に打放しコンクリートを施工するための課題として、統計的 根拠に基づいた外観の管理基準の目安を示すことが必要といえる。

コンクリート工学系の学術誌において、コンクリートの外観を検 討対象とした研究論文が、限定的ながらも報告されている。たとえ ば、岡島ら 1) は、コンクリート素地仕上げに対する感覚的評価をク ラスター分析によって 3 つに分類した。劉ら 2) は、着色材料を用い た打放しコンクリートの外観に対するイメージと表面の特性值との 関係を、因子分析および重回帰分析によって検討した。著者ら 3) は、 共分散構造分析を通じて表面の特性值からコンクリート外観に対す る印象が構築されるモデルを提案した。これらの先行研究は、コン クリートの外観の管理基準を検討したものではない。

施工中に生じるコンクリートの不具合のうち、表面気泡は、型枠
バイブレータの加振によって減少することが広く知られている ${ }^{4)}$ 。 コールドジョイントに関しては、過度なものを防止するための基準 が明確にされている。たとえば日本建築学会 5) は、打重社時間間隔 の限度の一般的な目安を、外気温が $25^{\circ} \mathrm{C}$ 未満の場合 150 分 $\left(25^{\circ} \mathrm{C}\right.$ 以上の場合 120 分）と寸る見解を示している。しかしながら、表面 気泡およびコールドジョイントの外観が許容される限界については、 必ずしも明らかにされていない。

外観の限界が唯一定量的に示されているコンクリートの不具合は、 ひび割れである。Haldane ${ }^{6)}$ は、小型コンクリート板に導入された ひび割れを評価するアンケート調査を実施し、0.25 mm を超えるひ び割れ幅が著しい不満を引き起こす可能性が高いことを指摘した。 fib7) は、Campbell-Allen の調査結果 8) を採用し、ひび割れ幅を 0.3 $\mathrm{mm}$ に制限することで許容される外観を実現できるとしている。 Eurocode $2^{9)}$ は、一般的に外観上許容できるひび割れ幅の限界を 0.4 $\mathrm{mm}$ としている。これらの限界值の根拠資料は、アンケート調查の 単なる集計結果や単回帰分析などの比較的簡便な統計分析の結果を 示すにとどまる。また、ひび割れ幅の限界に作用する因子として、 評価者の職業、観察距離および建物用途の影響が報告されているも のの、他の因子の影響に議論の余地が残る。

本論文では、打放しコンクリートの代表的な不具合である表面気 泡、ひび割れ、コールドジョイントおよび污れの外観を主たる検討 対象とした。供試体および実建築物に生じた不具合を評価するアン
*1 北九州市立大学国際環境工学部建築デザイン学科 准教授·博士 (工学)

*2 北九州市立大学国際環境工学部建築デザイン学科 教授・博士 (工学)
Assoc. Prof., Dept. of Architecture, Faculty of Environmental Engineering, The Univ. of Kitakyushu, Dr.Eng.

Prof., Dept. of Architecture, Faculty of Environmental Engineering, The Univ. of Kitakyushu, Dr.Eng. 
ケート調査を実施した。調査結果を主に二項ロジスティック回帰分 析注 1) し、不具合の外観の評価に影響する因子の抽出・定量化を通 じ、不具合の外観が許容される限界について検討した。

\section{2. 表面気泡の感性評価}

\section{1 調査概要}

本章ではコンクリート供試体に生じた表面気泡を評価対象とし、 アンケート調查および調查結果の分析を実施した。アンケート調查 に用いた 10 体の供試体（記号：BH01 10）の外観を Photo 1 に示 す。コンクリートに使用した主な材料は、普通ポルドランドセメン 卜 (密度 $3.16 \mathrm{~g} / \mathrm{cm}^{3}$ )、海砂（表乾密度 $2.58 \mathrm{~g} / \mathrm{cm}^{3}$ 、粗粒率 2.55 ）お よび砕石（表乾密度 $2.70 \mathrm{~g} / \mathrm{cm}^{3}$ 、実積率 $58.9 \%$ 、最大寸法 $20 \mathrm{~mm}$ ) である。調合は、水セメント比 0.50 、単位水量 $175 \mathrm{~kg} / \mathrm{m}^{3}$ 、単位粗 骨材かさ容積 $0.59 \mathrm{~m}^{3} / \mathrm{m}^{3}$ の 1 水準とした。コンクリート型枠用塗 装合板で作成した型枠内にコンクリートを打込み、幅 $450 \mathrm{~mm}$ x 高 さ $450 \mathrm{~mm} \mathrm{x}$ 厚さ $30 \mathrm{~mm}$ の寸法に供試体を成形した。表面気泡の 程度を調整するため、打込み時に木桘による打撃回数を 0 ～ 360 回、 もしくは型枠バイブレータによる加振時間を 0 ～20 秒の範囲で変動 させた。打込み後、7 日間型枠から外さずに約 $20^{\circ} \mathrm{C} の$ 恒温環境下で 封かん養生した後、21 日間以上気中養生したうえで、表面の明度が 安定したことを目視で確認してから供試体をアンケート調査に使用 した。

アンケート調査の直前に供試体の観察面を撮影し、得られた画像
を用いて表面気泡を定量化した。撮影は暗室内で、Fig. 1 の通り、 2 個のスポットライト注 2) (ビーム角度 $30^{\circ}$ 、ビーム光束 $2000 \mathrm{~lm}$ 、 色温度 $3100 \mathrm{~K})$ の光を観察面に対して平行に当てることで表面気 泡の影を作りながら行った。使用したデジタルカメラのホワイトバ ランスは $3600 \mathrm{~K} 、$ ISO 感度は 800、シャッタースピードは $1 / 125$ 秒、

$\mathrm{F}$ 值は 4 に設定した。得られた画像を白黒の 2 段調化注 3) したとき の明度の境界は、10 名の被験者（21～24 歳、男女比 5:5）が「実物 の表面気泡のみを黒に変換している」と選択した中央值を採用した。 2 段調化した画像における観察面の全面積に対する黒の面積（三表 面気泡の面積）の比を、本論文では表面気泡面積比（Bug hole area ratio）と定義する。得られた表面気泡面積比を Table 1 に示す。な お、同表には供試体毎の表面気泡の最大径、並びに観察面の 37 点

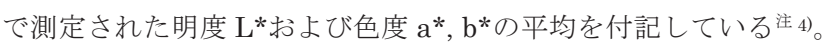

表面気泡に関するアンケート調查では、1 列に並べた供試体を被 験者に観察してもらいながら、「表面の気泡が、気になる一気になら ない」、美観上、許容できない一許容できる」および「構造上、不 安を感じる一不安を感じない」の 3 つの質問に対して 2 段階評価で 回答してもらった。10 体の供試体は、観察面に天空光のみが入射す るよう北に向け、 $10^{\circ}$ に傾け注 5)、横一列に並べられた。供試体の並 び順は無作為に決定し、調查期間中に複数回の並び替えを行った。 被験者に対する供試体の見せ方を Fig. 2 に示す。被験者には、観察 面の中心から $200 \mathrm{~mm}$ の範囲内のみを見せた。被験者の視点から観 察面までの距離（観察距離）は、0.5, 1.0, 1.5, 2.0, $2.5 \mathrm{~m} の 5$ 水準

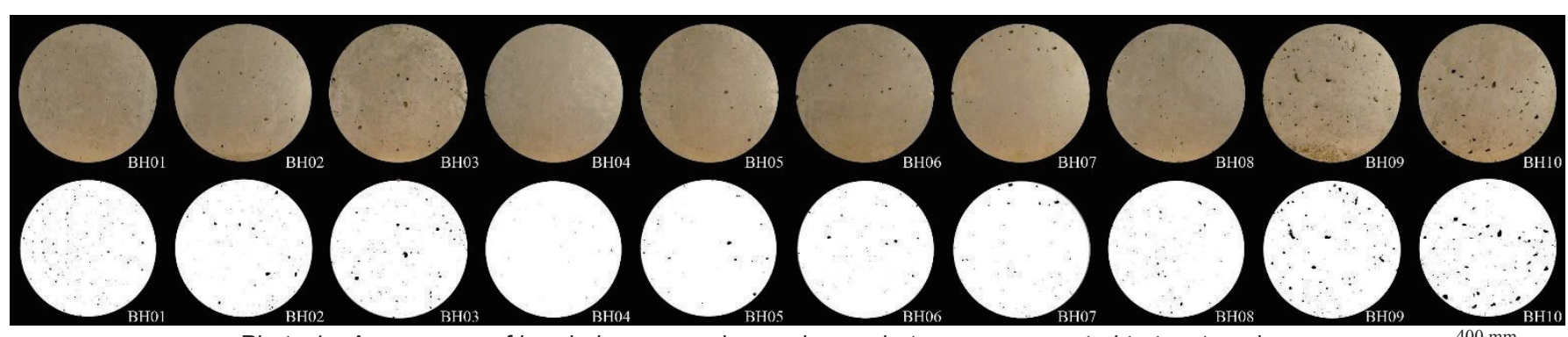

Photo 1 Appearance of bug-holes on specimens; lower photos were converted to two-tone images

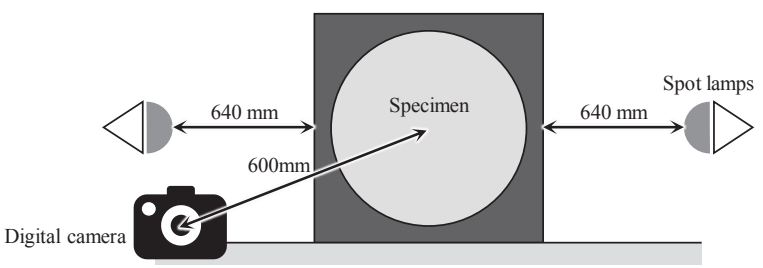

Fig. 1 Position of specimens to measure bug-hole area ratio

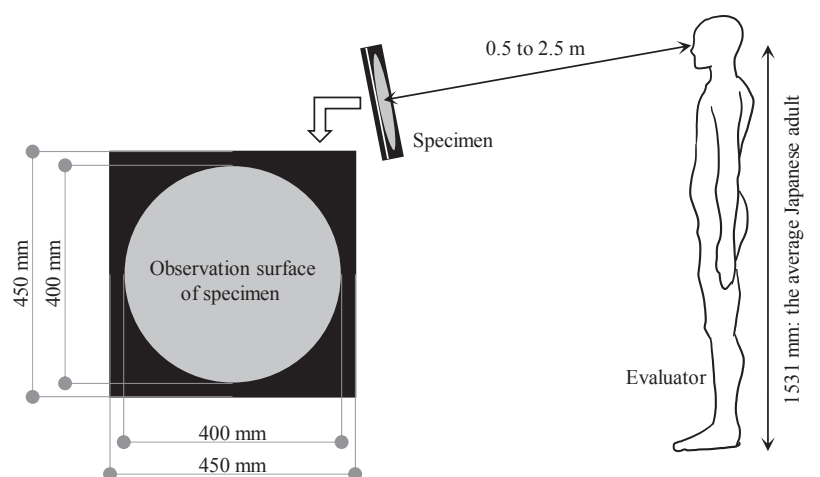

Fig. 2 Position of specimens and evaluators

Table 1 Characteristics of specimens and results on bug-holes survey

\begin{tabular}{|c|c|c|c|c|c|c|c|c|c|c|c|}
\hline No. & BH01 & $\mathrm{BH} 02$ & $\mathrm{BH} 03$ & BH04 & BH05 & BH06 & BH07 & BH08 & BH09 & BH10 & (Ave.) \\
\hline Bug-hole area ratio & $0.609 \%$ & $0.537 \%$ & $0.845 \%$ & $0.040 \%$ & $0.335 \%$ & $0.335 \%$ & $0.412 \%$ & $0.451 \%$ & $1.451 \%$ & $1.823 \%$ & $(0.684 \%)$ \\
\hline $\mathrm{L}^{*}$ (Average) & 71.17 & 69.49 & 71.25 & 71.25 & 71.16 & 68.53 & 72.43 & 69.71 & 71.74 & 70.92 & $(70.76)$ \\
\hline "I'm bothered by the air bubbles on the surface" & $54.0 \%$ & $55.5 \%$ & $92.0 \%$ & $10.0 \%$ & $54.0 \%$ & $43.5 \%$ & $57.0 \%$ & $58.0 \%$ & $92.5 \%$ & $93.0 \%$ & $(61.0 \%)$ \\
\hline "aesthetically unacceptable" & $41.0 \%$ & $41.0 \%$ & $85.5 \%$ & $12.5 \%$ & $40.5 \%$ & $35.0 \%$ & $51.0 \%$ & $50.5 \%$ & $87.5 \%$ & $88.5 \%$ & $(53.3 \%)$ \\
\hline "worrying from a structural standpoint" & $21.0 \%$ & $30.0 \%$ & $66.5 \%$ & $6.5 \%$ & $21.5 \%$ & $18.0 \%$ & $24.0 \%$ & $29.0 \%$ & $68.0 \%$ & $73.5 \%$ & $(35.8 \%)$ \\
\hline
\end{tabular}


から、評価しや寸い位置を被験者に選んでもらった注6)。アンケート 調查の状況を Photo 2 に示す。

アンケート調査の期間は 2018 年 10 月 16 日〜 11 月 11 日、場所 は北九州市本城公園、北九州市響灘緑地および北九州市立大学ひび きのキャンパス内とした。被験者は、当日に実施場所で募集に応じ た 200 名である。7 90 歳の日本の人口分布に合わせて男女別に人 数をそれぞれ 10 等分し、男女別の各世代に約 10 人ずつ割り当てる よう被験者を抽出した。被験者の属性、被験者が申告した視力、観 察距離、調査時の気温、相対湿度および供試体観察面の照度の分布 をTable 2 に示す。

\section{2 調査結果}

10 体の供試体に対して「表面の気泡が気になる」、「美観上、許容 できない」および「構造上、不安を感じる」と回答した被験者の割 合は、Table 1 に示した通りである。表面気泡面積比が大きい供試 体ほど、被験者は表面気泡を気にし、美観的に許容できなくなり、 構造的に不安を感じ易くなる傾向が確認された。なお、別途調查時 に行ったヒアリングでは、表面気泡の総面積が比較的小さくても、 表面気泡の数が多い供試体（たとえば BH03）を美観的に許容でき ないという被験者のコメントが散見された。

\section{3 分析および考察}

アンケート調査の結果を用いて二項ロジスティック回帰分析を実 施した注7)。被験者の回答を目的変数とし、供試体の「表面の気泡が 気にならない」と回答した場合を 0、「気になる」と回答した場合を 1 とした。説明変数には、表面気泡面積比、被験者の年齢、性別、 視力、観察距離、気温、相対湿度および観察面の照度を投じた。尤 度比・変数増加法による分析結果を Table 3 に示す。モデル $\chi^{2}$ 検定 の結果は $p<.001$ で有意であり、表面気泡面積比、被験者の性別、 相対湿度および観察面の照度が有意 $(p<.05)$ な説明変数であった。 得られたオッズ比から、表面気泡面積比および被験者の性別が、表 面気泡の評価に比較的大きい影響を与えた因子と考察される。被験 者が「表面の気泡が気になる」と回答する確率は、表面気泡面積比 が $1 \%$ 増加すると 18 倍に増加することが推定された。また、男性の 方が表面気泡に対して寛大な評価をする傾向が認められ、男性が表 面気泡を気にする確率は女性の 0.53 倍になることが推定された。な お、Table 3 に記載されていない説明変数は、有意確率 $(p=.05)$ を上回ったため最終的な回帰式から除外された変数である。これら は、被験者の回答への影響が認められなかった因子といえる。

得られた偏回帰係数を用いて、被験者の $50 \%$ が「表面の気泡が気 にならない」と回答する表面気泡面積比の限界を推定すると、その 值は女性において $0.30 \%$ 、男性において $0.53 \%$ となる注 8$)$ 。本論文で は、これらをコンクリートの外観の限界のひとつとして提案する。

目的変数を「美観上、許容できる」と回答した場合を 0 、「許容で きない」と回答した場合を 1 とした分析結果を Table 4 に示す。被 験者の $50 \%$ が「美観上、許容できる」と回答する表面気泡面積比の 限界は、被験者が女性の場合 $0.44 \%$ 、男性の場合 $0.69 \%$ と推定され る。同様に、目的変数を「構造上、不安を感じない」と回答した場 合を 0 、「不安を感じる」と回答した場合を 1 とした分析結果を Table 5 に示す。被験者の $50 \%$ 構造上、不安を感じない」と回答する 表面気泡面積比の限界は、被験者が女性の場合 $0.85 \%$ 、男性の場合 $1.22 \%$ 、と推定される。

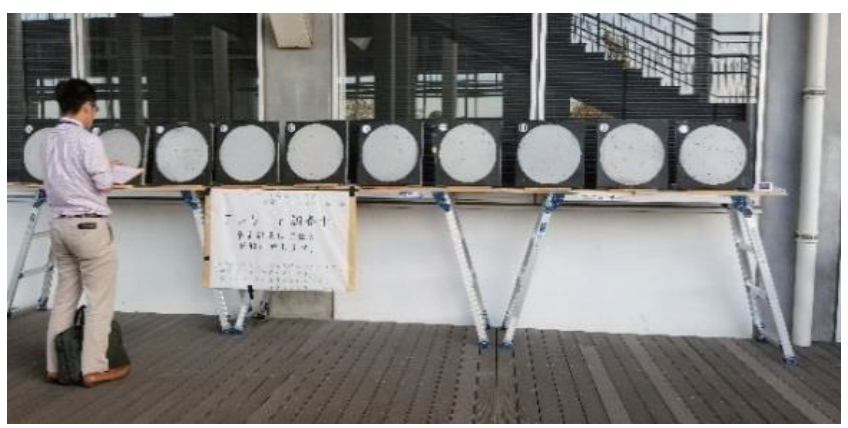

Photo 2 Questionnaire survey of bug-holes on specimens

Table 2 Evaluators $(N=200)$ and surrounding on bug-holes survey

\begin{tabular}{lcccccr} 
& Min. & $25 \%$ & Med. & $75 \%$ & Max. & \multicolumn{1}{c}{ (Ave.) } \\
\hline Evaluator age, years & 7 & 31 & 48 & 69 & 87 & $(48.4)$ \\
Evaluator gender & Female & $(102) ;$ Male $(98)$ & & & \\
Evaluator visual acuity & 0.1 & 0.8 & 1.0 & 1.2 & 2.0 & $(1.04)$ \\
Distance chosen by evaluator & $0.5 \mathrm{~m}(3) ; 1.0 \mathrm{~m}$ & $(22) ; 1.5 \mathrm{~m}$ & $(40) ; 2.0$ & $\mathrm{~m}(125) ;$ & 2.5 \\
Temperature, degree C & 15.6 & 17.6 & 19.9 & 21.8 & 24.6 & $(19.8)$ \\
Relative humidity & $39 \%$ & $48 \%$ & $54.5 \%$ & $57 \%$ & $60 \%$ & $(52.3 \%)$ \\
Illuminance, $\mathrm{lx}$ & 430 & 1127 & 1267.5 & 3005 & 4275 & $(2074)$ \\
\hline
\end{tabular}

Table 3 Result of logistic regression analysis / bug-holes (1) Objective variable:

"I'm not bothered by the air bubbles on the surface" $=0$, "I'm bothered" $=1$

\begin{tabular}{lrcrrr}
\multicolumn{1}{c}{ Explanatory variable } & $\begin{array}{r}\text { Regression } \\
\text { coefficient }\end{array}$ & \multicolumn{1}{c}{$p$} & Odds ratio & $95 \%$ lower & $95 \%$ upper \\
\hline Bug-hole area ratio, \% & 2.871 & $<.001$ & $\mathbf{1 7 . 6 5 0}$ & 12.362 & 25.200 \\
Gender, female $=\mathbf{0}$; male=1 & -0.644 & $<.001$ & $\mathbf{0 . 5 2 5}$ & 0.427 & 0.646 \\
Relative humidity, \% & -0.023 & .012 & 0.977 & 0.959 & 0.995 \\
Illuminance, klx & 0.154 & .002 & 1.167 & 1.056 & 1.289 \\
Constant & 0.034 & & & \\
& & & \\
& & & in $\chi^{2}$ test $<.001$, Percentage correct $=71.9$
\end{tabular}

Table 4 Result of logistic regression analysis / bug-holes (2)

\begin{tabular}{lrcrrr}
\hline \multicolumn{1}{c}{ Objective variable: "aesthetically acceptable" $=0$, "unacceptable" $=1$} \\
\hline Explanatory variable & $\begin{array}{r}\text { Regression } \\
\text { coefficient }\end{array}$ & $p$ & Odds ratio & $95 \%$ lower & $95 \%$ upper \\
\hline Bug-hole area ratio, \% & 2.331 & $<.001$ & $\mathbf{1 0 . 2 8 9}$ & 7.815 & 13.547 \\
Gender, female=0; male=1 & -0.597 & $<.001$ & $\mathbf{0 . 5 5 1}$ & 0.451 & 0.672 \\
Temperature, degree C & 0.073 & $<.001$ & 1.076 & 1.034 & 1.120 \\
Constant & -2.473 & & & &
\end{tabular}

Constant

$p$ in $\chi^{2}$ test $<.001$, Percentage correct $=70.4$

Table 5 Result of logistic regression analysis / bug-holes (3)

\begin{tabular}{lrlrrr}
\hline \multicolumn{6}{c}{ Objective variable: "not worrying from a structural standpoint" $=0$, "worrying" $=1$} \\
\hline Explanatory variable & $\begin{array}{r}\text { Regression } \\
\text { coefficient }\end{array}$ & \multicolumn{1}{c}{$p$} & Odds ratio & $95 \%$ lower & $95 \%$ upper \\
\hline Bug-hole area ratio, \% & 1.976 & $<.001$ & $\mathbf{7 . 2 1 6}$ & 5.809 & 8.963 \\
Gender, female=0; male=1 & -0.741 & $<.001$ & $\mathbf{0 . 4 7 7}$ & 0.385 & 0.591 \\
Evaluator age, years & 0.006 & .029 & 1.006 & 1.001 & 1.011 \\
Relative humidity, \% & -0.070 & $<.001$ & 0.933 & 0.915 & 0.951 \\
Illuminance, klx & 0.340 & $<.001$ & 1.404 & 1.262 & 1.563 \\
Constant & 0.999 & & & &
\end{tabular}

Constant

$p$ in $\chi^{2}$ test $<.001$, Percentage correct $=73.5$

\section{3.ひび割れの感性評価}

\section{1 調査概要}

本章では、コンクリート供試体の表面に生じたひび割れを評価対 象とした。アンケート調査には、10 体の供試体（記号 : Cr01〜10、

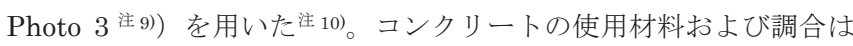
前章と同じとした。供試体の寸法は、幅 $450 \mathrm{~mm} \mathrm{x}$ 高さ $450 \mathrm{~mm} \mathrm{x}$ 厚さ $60 \mathrm{~mm}$ とした。供試体の中央付近にひび割れを生じさせるた め、観察面裏の型枠に半円断面（直径 $20 \mathrm{~mm}$ ）のゴムを接着して観 察面裏の中央を凹ませた。また、ひび割れ導入後に供試体が完全に 割れないよう、直径 $6 \mathrm{~mm}$ の丸鋼を鉛直方向に 3 本配笳した。打込 みに際しては、表面気泡の発生を抑制するため、木桘で吒きながら 打ち込むなどの対策を施した。打込み後の供試体の養生方法は、前 章と同じとした。観察面のひび割れは、材齢 28 日の供試体に曲げ 荷重をかけることで導入した。 


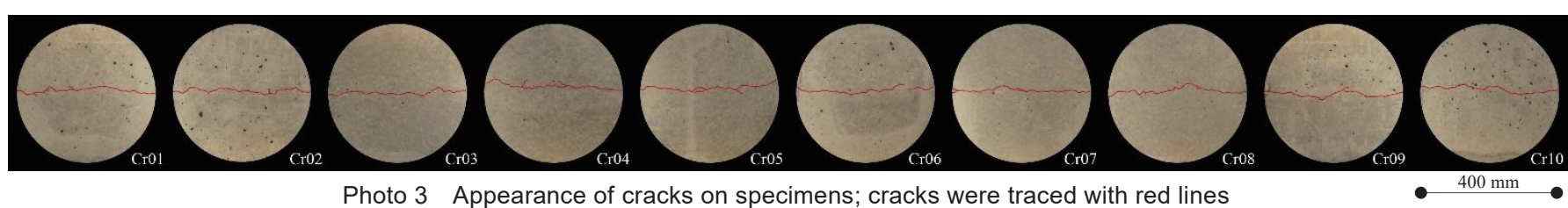

Table 6 Characteristics of specimens and results on crack survey

\begin{tabular}{|c|c|c|c|c|c|c|c|c|c|c|c|}
\hline No. & $\mathrm{Cr} 01$ & $\mathrm{Cr} 02$ & $\mathrm{Cr} 03$ & $\mathrm{Cr} 04$ & $\mathrm{Cr} 05$ & $\mathrm{Cr} 06$ & $\mathrm{Cr} 07$ & Cr08 & Cr09 & Cr10 & (Ave.) \\
\hline Crack width, mm & 0.145 & 0.225 & 0.097 & 0.175 & 0.190 & 0.115 & 0.270 & 0.170 & 0.365 & 0.123 & $(0.188)$ \\
\hline Bug-hole area ratio & $0.357 \%$ & $0.459 \%$ & $0.039 \%$ & $0.056 \%$ & $0.063 \%$ & $0.399 \%$ & $0.087 \%$ & $0.102 \%$ & $1.181 \%$ & $1.238 \%$ & $(0.398 \%)$ \\
\hline $\mathrm{L}^{*}$ (Average) & 67.71 & 68.24 & 65.61 & 65.41 & 66.15 & 67.60 & 65.93 & 66.44 & 67.95 & 66.90 & (66.79) \\
\hline$a *$ (Average) & -0.37 & -0.42 & -0.68 & -0.65 & -0.66 & -0.51 & -0.69 & -0.63 & -0.47 & -0.47 & $(-0.37)$ \\
\hline $\mathrm{b}^{*}$ (Average) & 4.57 & 4.20 & 3.57 & 3.66 & 3.52 & 4.00 & 3.39 & 3.51 & 3.93 & 4.16 & (4.57) \\
\hline "I'm bothered by the crack" & $41.5 \%$ & $77.5 \%$ & $12.0 \%$ & $51.0 \%$ & $67.5 \%$ & $20.0 \%$ & $88.5 \%$ & $39.5 \%$ & $91.5 \%$ & $28.0 \%$ & $(51.7 \%)$ \\
\hline "aesthetically unacceptable" & $38.5 \%$ & $64.5 \%$ & $9.0 \%$ & $39.5 \%$ & $55.5 \%$ & $20.0 \%$ & $80.5 \%$ & $30.0 \%$ & $84.0 \%$ & $32.5 \%$ & $(45.4 \%)$ \\
\hline "worrying from a structural standpoint" & $33.5 \%$ & $57.0 \%$ & $10.0 \%$ & $43.0 \%$ & $53.0 \%$ & $19.5 \%$ & $75.5 \%$ & $31.0 \%$ & $85.0 \%$ & $26.5 \%$ & $(43.4 \%)$ \\
\hline
\end{tabular}

アンケート調査の直前に、各供試体の観察面に生じた最大のひび 割れ幅を、10 名の測定者（22～24 歳、男女比 5:5）に市販のクラッ クスケールを用いて測ってもらった。このとき、透明樹脂製および ステンレス製の 2 種類のクラックスケールを、それぞれ 5 名ずつに 無作為に割り当てた。10 名が測定したひび割れ幅の平均を、他の特 性值と併せて Table 6 に示す。

ひび割れに関するアンケート調査では、被験者（200 名）に供試 体を観察してもらいながら、「ひび割れが、気になる一気にならない小、 「美観上、許容できない一許容できる」および「構造上、不安を感じ る一不安を感じない」の 3 つの質問に対して 2 段階評価で回答して もらった。被験者に対する供試体の展示方法などは前章の調査と同 じとした。アンケート調查の期間は 2019 年 1 月 19, 20 日、場所は 北九州市響灘緑地とした。被験者の属性および調查時の気象情報の 分布を Table 7 に示す。

\section{2 調査結果、分析および考察}

アンケート調査の結果は、Table 6 に示した通りである。ひび割 れ幅が大きいほじ、「ひび割れが気になる」、美観上、許容できない」、

「構造上、不安を感じる」の回答割合が増加した。

アンケート調査の結果を用いて二項ロジスティック回帰分析を実 施した。被験者の回答を目的変数とし、供試体の「ひび割れが気に ならない」と回答した場合を 0 、「気になる」と回答した場合を 1 と した。説明変数には、ひび割れ幅、表面気泡面積比、被験者の年齢、 性別、視力、観察距離、気温、相対湿度および観察面の照度を投じ た。尤度比・変数増加法による分析結果を Table 8 に示す。モデル $\chi^{2}$ 検定の結果は $p<.001$ で有意であり、ひび割れ幅、被験者の性別 および観察距離が有意 $(p<.05)$ な説明変数であった。得られたオ ッズ比から、被験者が「ひび割れが気になる」と回答する確率は、 ひび割れ幅が $0.1 \mathrm{~mm}$ 増加すると 7.1 倍に増加することが推定され た。また、観察距離が $1 \mathrm{~m}$ 増加すると、同確率が 0.73 倍に減少す ることが推定された。表面気泡の評価と同様に、男性の方が女性よ りひび割れに対しても寛大な評価をする傾向が認められた。一方、 表面気泡面積比が最終的な回帰式から除外されたことから、供試体 に生じた表面気泡が、ひび割れの評価に与える影響は認められなか ったといえる。

同様に、目的関数を「美観上、許容できる」と回答した場合を 0 、 「許容できない」と回答した場合を 1 とした分析結果を Table 9、 「構造上、不安を感じない」と回答した場合を0、「不安を感じる」 と回答した場合を 1 とした分析結果を Table 10 に示す。得られた
Table 7 Evaluators $(N=200)$ and surrounding on crack survey

\begin{tabular}{lrrrrrr}
\hline & Min. & $25 \%$ & Med. & $75 \%$ & Max. & \multicolumn{1}{c}{ (Ave.) } \\
\hline Evaluator age, years & 7 & 31 & 44.5 & 62 & 85 & $(45.3)$ \\
Evaluator gender & Female & $(104)$; Male $(96)$ & & & \\
Evaluator visual acuity & 0.0 & 0.7 & 1.0 & 1.3 & 2.0 & $(1.02)$ \\
Distance chosen by evaluator & $0.5 \mathrm{~m}(17) ; 1.0$ & $(55) ; 1.5$ & $(24) ;$ & $2.0 \mathrm{~m}(98) ; 2.5 \mathrm{~m}(6)$ \\
Temperature, degree C & 9.0 & 10.0 & 11.0 & 15.1 & 16.9 & $(12.1)$ \\
Relative humidity & $35 \%$ & $40 \%$ & $51 \%$ & $61 \%$ & $62 \%$ & $(51.2 \%)$ \\
Illuminance, lx & 914 & 1022 & 1155 & 1365 & 1723 & $(1204)$ \\
\hline
\end{tabular}

Table 8 Result of logistic regression analysis / crack (1) Objective variable: "I'm not bothered by the crack" $=0$, "I'm bothered" $=1$

\begin{tabular}{lrcrrr}
\multicolumn{1}{c}{ Explanatory variable } & $\begin{array}{r}\text { Regression } \\
\text { coefficient }\end{array}$ & \multicolumn{1}{c}{$p$} & Odds ratio & $95 \%$ lower & $95 \%$ upper \\
\hline Crack width, $\mathbf{0 . 1} \mathbf{~ m m}$ & 1.959 & $<.001$ & $\mathbf{7 . 0 9 3}$ & 5.784 & 8.698 \\
Gender; female $=0$, male=1 & -0.358 & .001 & 0.699 & 0.568 & 0.859 \\
Viewing distance, $\mathbf{m}$ & -0.314 & .001 & $\mathbf{0 . 7 3 0}$ & 0.606 & 0.880 \\
Constant & -2.761 & & & & \\
\hline
\end{tabular}

$p$ in $\chi^{2}$ test $<.001$, Percentage correct $=73.2$

Table 9 Result of logistic regression analysis / crack (2) Objective variable: "aesthetically acceptable" $=0$, "unacceptable" $=1$

\begin{tabular}{lrrrrr}
\hline Explanatory variable & $\begin{array}{r}\text { Regression } \\
\text { coefficient }\end{array}$ & \multicolumn{1}{c}{$p$} & Odds ratio & $95 \%$ lower & $95 \%$ upper \\
\hline Crack width, $\mathbf{0 . 1} \mathbf{~ m m}$ & 1.455 & $<.001$ & $\mathbf{4 . 2 8 5}$ & 3.642 & 5.041 \\
Temperature, degree C & -0.159 & .005 & 0.853 & 0.763 & 0.954 \\
Relative humidity, \% & -0.046 & .001 & 0.955 & 0.929 & 0.981 \\
Viewing distance, $\mathbf{m}$ & -0.296 & .001 & $\mathbf{0 . 7 4 4}$ & 0.621 & 0.891 \\
Constant & 1.864 & & & & \\
\hline
\end{tabular}

$p$ in $\chi^{2}$ test $<.001$, Percentage correct $=70.7$

Table 10 Result of logistic regression analysis / crack (3) Objective variable: "not worrying from a structural standpoint" $=0$, "worrying" $=1$

\begin{tabular}{lrrrrr}
\multicolumn{1}{c}{ Explanatory variable } & $\begin{array}{r}\text { Regression } \\
\text { coefficient }\end{array}$ & \multicolumn{1}{c}{$p$} & Odds ratio & $95 \%$ lower & $95 \%$ upper \\
\hline Crack width, $\mathbf{0 . 1} \mathbf{~ m m}$ & 1.445 & $<.001$ & $\mathbf{4 . 2 4 2}$ & 3.613 & 4.980 \\
Gender, female $=0$; male=1 & -0.296 & .004 & 0.744 & 0.608 & 0.910 \\
Evaluator age, years & 0.008 & .002 & 1.008 & 1.003 & 1.014 \\
Visual acuity & 0.323 & .010 & 1.381 & 1.080 & 1.766 \\
Viewing distance, $\mathbf{m}$ & -0.453 & $<.001$ & $\mathbf{0 . 6 3 6}$ & 0.529 & 0.764
\end{tabular}

Viewing distance, $\mathrm{n}$ $-2.830$

$p$ in $\chi^{2}$ test $<.001$, Percentage correct $=70.7$

Table 11 Limits defined by acceptable appearance; unit: $\mathrm{mm}$

\begin{tabular}{lrrrrr}
\hline \multirow{2}{*}{ Crack width for which $50 \%$ of evaluators responded... } & 0.5 & 1.0 & 1.5 & 2.0 & 2.5 \\
\hline "I'm not bothered" & 0.16 & 0.17 & 0.17 & 0.18 & 0.19 \\
"aesthetically acceptable" & 0.18 & 0.19 & 0.20 & 0.21 & 0.22
\end{tabular}

"not worrying from a structural standpoint" 0.17

偏回帰係数を用いて、被験者の $50 \%$ が「ひび割れが気にならない、

「美観上、許容できる」および「構造上、不安を感じない」と回答 するひび割れ幅の限界は、Table 11 の通り推定される注11)。また、 日本建築学会 11) が一般環境下において劣化抵抗性を確保するため の許容值（屋外）として定めた $0.3 \mathrm{~mm}$ のひび割れ幅を、被験者の $92 \%$ が気にし、 $82 \%$ 美観的に許容できず、 $80 \%$ が構造的に不安を 感じることが推定される（被験者の選択した観察距離が、調查時の 平均である $1.6 \mathrm{~m}$ の場合)。 


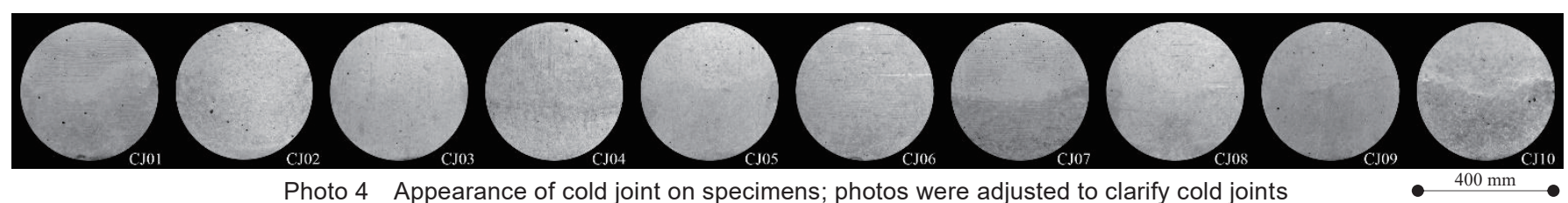

Table 12 Characteristics of specimens and results on cold joint survey

\begin{tabular}{|c|c|c|c|c|c|c|c|c|c|c|c|}
\hline No. & CJ01 & CJ02 & CJ03 & CJ04 & CJ05 & CJ06 & CJ07 & CJ08 & CJ09 & CJ10 & (Ave.) \\
\hline Placing joint time interval, hours & 2.0 & 3.0 & $\mathbf{0}$ & 1.0 & 1.0 & 2.0 & 1.5 & 1.5 & 2.0 & 2.0 & \\
\hline Water cement ratio & 0.65 & 0.50 & 0.50 & 0.40 & 0.50 & 0.40 & 0.65 & 0.50 & 0.50 & 0.50 & \\
\hline Difference in lightness $\Delta L_{1}$ & 1.55 & 1.77 & 1.00 & 1.47 & 1.29 & 1.45 & 2.51 & 1.34 & 1.13 & 2.57 & $(1.61)$ \\
\hline Difference in lightness $\Delta L_{2}$ & 1.24 & 0.93 & 0.13 & 0.51 & 1.00 & 1.29 & 3.62 & 1.58 & 1.13 & 3.84 & (1.53) \\
\hline Difference in lightness $\Delta L_{3}$ & 3.41 & 3.31 & 2.55 & 4.68 & 3.55 & 4.55 & 7.05 & 3.85 & 3.27 & 7.96 & $(4.42)$ \\
\hline Difference in lightness $\Delta L_{4}$ & 2.59 & 2.94 & 0.62 & 5.32 & 1.40 & 0.86 & 5.17 & 1.55 & 2.07 & 4.59 & $(2.71)$ \\
\hline Bug-hole area ratio & $0.208 \%$ & $0.282 \%$ & $0.119 \%$ & $0.164 \%$ & $0.120 \%$ & $0.119 \%$ & $0.252 \%$ & $0.122 \%$ & $0.121 \%$ & $0.210 \%$ & $(0.172 \%)$ \\
\hline $\mathrm{L}^{*}$ (Average) & 70.26 & 71.55 & 70.41 & 66.25 & 69.61 & 69.30 & 68.93 & 69.35 & 70.01 & 67.61 & $(69.33)$ \\
\hline $\mathrm{a}^{*}$ (Average) & -0.35 & -0.36 & -0.30 & -0.27 & -0.32 & -0.19 & -0.32 & -0.25 & -0.36 & -0.36 & $(-0.31)$ \\
\hline $\mathrm{b}^{*}$ (Average) & 4.19 & 4.12 & 5.03 & 5.01 & 4.65 & 5.09 & 4.60 & 4.58 & 4.47 & 4.85 & (4.66) \\
\hline \multicolumn{12}{|l|}{ "I'm bothered by ..." } \\
\hline cold joint & $1.0 \%$ & $0.0 \%$ & $0.5 \%$ & $4.0 \%$ & $1.5 \%$ & $2.5 \%$ & $10.5 \%$ & $2.0 \%$ & $13.0 \%$ & $20.0 \%$ & $(5.5 \%)$ \\
\hline bug-holes & $50.0 \%$ & $58.0 \%$ & $12.0 \%$ & $26.5 \%$ & $19.0 \%$ & $3.5 \%$ & $39.5 \%$ & $18.0 \%$ & $27.0 \%$ & $44.5 \%$ & $(29.8 \%)$ \\
\hline print of form & $14.0 \%$ & $0.5 \%$ & $17.5 \%$ & $24.0 \%$ & $10.0 \%$ & $16.0 \%$ & $16.5 \%$ & $6.0 \%$ & $4.0 \%$ & $1.0 \%$ & $(11.0 \%)$ \\
\hline mottling, excluding cold joint & $9.0 \%$ & $0.5 \%$ & $2.0 \%$ & $3.5 \%$ & $1.5 \%$ & $0.0 \%$ & $7.5 \%$ & $5.0 \%$ & $1.5 \%$ & $5.5 \%$ & $(3.6 \%)$ \\
\hline reflection & $6.0 \%$ & $0.5 \%$ & $4.0 \%$ & $4.0 \%$ & $1.5 \%$ & $0.5 \%$ & $1.5 \%$ & $1.0 \%$ & $0.5 \%$ & $0.0 \%$ & $(2.0 \%)$ \\
\hline staining & $3.5 \%$ & $1.0 \%$ & $5.5 \%$ & $8.5 \%$ & $6.0 \%$ & $1.0 \%$ & $9.0 \%$ & $5.0 \%$ & $4.5 \%$ & $10.0 \%$ & $(5.4 \%)$ \\
\hline chip or crack & $31.0 \%$ & $10.5 \%$ & $5.5 \%$ & $14.0 \%$ & $7.0 \%$ & $18.0 \%$ & $19.5 \%$ & $5.5 \%$ & $4.0 \%$ & $5.5 \%$ & $(12.1 \%)$ \\
\hline "The cold joint is aesthetically unacceptable" & $1.0 \%$ & $0.0 \%$ & $0.0 \%$ & $3.7 \%$ & $0.5 \%$ & $1.0 \%$ & $7.3 \%$ & $0.5 \%$ & $6.9 \%$ & $12.6 \%$ & $(3.4 \%)$ \\
\hline "I'm worried about the cold joint from a structural standpoint" & $0.0 \%$ & $0.0 \%$ & $0.0 \%$ & $1.6 \%$ & $0.5 \%$ & $0.5 \%$ & $3.7 \%$ & $0.5 \%$ & $3.2 \%$ & $6.8 \%$ & $(1.7 \%)$ \\
\hline
\end{tabular}

\section{4. コールドジョイントの感性評価}

\section{1 調査概要}

本章では、コンクリート供試体の表面に生じたコールドジョイン トを評価対象とした。アンケート調査には、10 体の供試体（記号： CJ01 10、Photo 4 注 9) ) を用いた。コンクリートの主な使用材料は、 普通ポルドランドセメント (密度 $3.14 \mathrm{~g} / \mathrm{cm}^{3}$ )、海砂 (表乾密度 2.57 $\mathrm{g} / \mathrm{cm}^{3}$ 、粗粒率 2.30 ) および砕石 (表乾密度 $2.74 \mathrm{~g} / \mathrm{cm}^{3}$ 、実積率 $59.7 \%$ 、 最大寸法 $20 \mathrm{~mm}$ ) である。コンクリートの調合は、水セメント比 $0.65,0.50,0.40$ の 3 水準とした。供試体の寸法は、幅 $450 \mathrm{~mm}$ x 高 さ $450 \mathrm{~mm}$ x 厚さ $30 \mathrm{~mm}$ とした。供試体にコールドジョイントを 発生させるため、およそ半分の高さで、0３時間の打重ね時間間隔 を設けてコンクリートを打ち重㸚た。打込み後の供試体の養生方法 は、前章までと同じとした。

コールドジョイントの外観を定量化するため、各供試体の観察面 で明度 $\mathrm{L}^{*}$ を測定した注 ${ }^{4)}$ 。 1 回の測定範囲を直径 $3 \mathrm{~mm}$ の円内に絞 り、1 供試体あたり Fig. 3 に示す 80 箇所で測定を繰り返した。こ のうち 50 箇所の $\mathrm{A}$ 位置では、目視で確認された打重齐線を基準に 上下 2 方向に $10 \mathrm{~mm}$ 間隔で 10 箇所の測定を、 $75 \mathrm{~mm}$ 間隔で 5 列 繰り返した。30 箇所の B 位置では、打重䃿線の位置、打ち重齐線か ら上下に約 $50 \mathrm{~mm}$ 離れた位置でそれぞれ 10 回測定した。本論文で は、以下に示す 4 つの明度 $\mathrm{L}^{*}$ 差 $\Delta L_{1}, \Delta L_{2}, \Delta L_{3}, \Delta L_{4}$ を、コールド ジョイントの外観を定量化する変数の案とした注 ${ }^{12) 。}$

$\Delta L_{1}: \mathrm{A}$ 位置 50 箇所で測定された 50 值の標準偏差。

$\Delta L_{2}$ : A 位置で測定された打重叔線近傍（4)～(7)）の20值、打重称 線上部（11) (3)）の 15 值、および打重㸚線下部（8)～(10) の 15 值でそれぞれ導出した平均（3 值）の最大最小の差。

$\Delta L_{3}: \mathrm{A}$ 位置で測定された各列 10 值の最大最小の差 (5 值)の平均。

$\Delta L_{4}: \mathrm{B}$ 位置で測定された打重ね線の 10 值、上側の 10 值、下側の 10 值でそれぞれ導出した平均（3 值）の最大最小の差。 各供試体の明度 $\mathrm{L}^{*}$ の差 $\Delta L_{1}, \Delta L_{2}, \Delta L_{3}, \Delta L_{4}$ を、観察面で測定された 他の特性値と併せて Table 12 に示す。

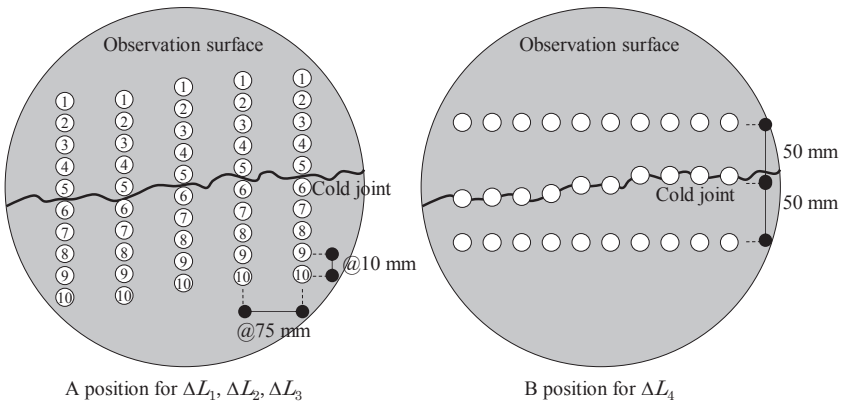

Fig. 3 Positions measuring lightness values $L^{*}$ to quantify cold joint

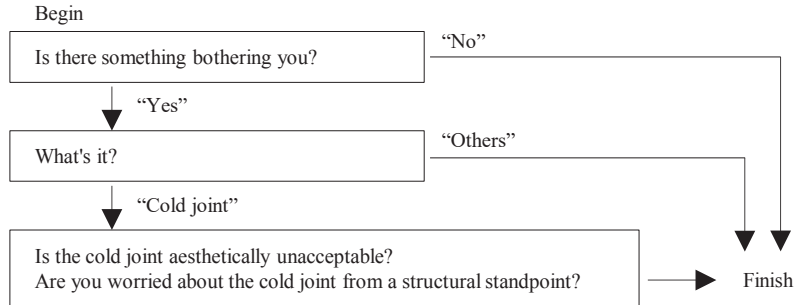

Fig. 4 Flowchart of questions on cold joint survey

コールドジョイントに関するアンケート調查では、試験者の質問 や説明が、被験者の意識を打重斌線に誘導しないよう配慮した。質 問の手順を Fig. 4 に示寸。被験者（200名）に供試体を観察しても らいながら、最初に「気になる箇所があるか」を質問した。気にな る箇所があると回答された場合、更に「何が気になるか」を質問し た。気になる箇所がコールドジョイントと試験者が判断した場合の み、コールドジョイントについて「美観上、許容できない一許容で きる」および「構造上、不安を感じる一不安を感じない」の質問に 2 段階評価で回答してもらった。被験者に対する供試体の見せ方な どは、前章までの調査と同じとした。アンケート調查の期間は 2019 年 11 月 9 日〜 16 日、場所は北九州市響灘緑地および北九州市立大 学ひびきのキャンパス内とした。被験者の属性および調查時の気象 情報の分布をTable 13 に示す。前章までの調査と比較して被験者が 
供試体を近い距離で観察しており、本章の供試体の不具合を認知し 難かった様子がうかがえた。

\section{2 調査結果}

被験者が気になる箇所として指摘した事象の割合は、Table 12 に 示した通りである。コールドジョイントが気になる箇所として指摘 された割合は、平均で $5.5 \%$ と比較的小さかった。特に表面気泡が指 摘された割合と比較した場合、全ての供試体において小さい值を示 した。コールドジョイントは、打重祇時間間隔を最大 3 時間として も、他の不具合と比較して注目され難いと考察される。

\section{3 分析および考察}

被験者の回答と、明度 $\mathrm{L} *$ の差 $\Delta L_{1}, \Delta L_{2}, \Delta L_{3}, \Delta L_{4}$ との関係を単回 帰分析して得られた相関係数を Table 14 に示す。分析では「コール ドジョイントが気になる」、「美観上、許容できない」および「構造 上、不安を感じる」を正とした。全ての組み合わせで正の相関関係 が認められ、 $\Delta L_{2}$ および $\Delta L_{3}$ の相関係数が比較的高かった。本論文の 範囲内において、コールドジョイントの外観を評価する変数には $\Delta L_{2}$ もくは $\Delta L_{3}$ を用いることが適切と考察される。

アンケート調査の結果を用いて二項ロジスティック回帰分析を実 施した。被験者の回答を目的変数とし、説明変数には明度 $\mathrm{L}^{*}$ の差 $\Delta L_{3}$ 、被験者の年齢、性別、視力、観察距離、気温、相対湿度および 観察面の照度を投じた。尤度比・变数増加法による分析結果を Table 15 17 に示す。モデル $\chi^{2}$ 検定の結果は、全て $p<.001$ で有意であ った。有意 $(p<.05)$ な説明変数のうち、明度 $\mathrm{L}^{*}$ の差 $\Delta L_{3}$ および被 験者の性別が顕著なオッズ比を示した。オッズ比は、供試体の明度 $\mathrm{L}^{*}$ 差 $\Delta L_{3}$ が大きいほどコールドジョイントに対する評価が厳しか った傾向を示す一方、表面気泡およびひび割れに対する評価と逆に、 女性の方が男性よりコールドジョイントを寛大に評価する傾向を示 した。この原因として、女性の方が表面気泡などの比較的目立つ不 具合に強く意識を向けた結果、打重祇線の見落としやコールドジョ イントの過小評価を引き起こしたことが推察される。

なお、本章の調查結果を用いて推定された被験者の $50 \%$ が表面気 泡を気にしない表面気泡面積比の限界は $0.25 \%$ あったた注 ${ }^{13)}$ この 值は、第 2 章で推定された值（女性 $0.30 \%$ ／男性 $0.53 \%$ ）より小さ い。本章の供試体の表面気泡に対する評価は、第 2 章の調查より厳 しかったといえる。両章の供試体において最大の表面気泡面積比が 6.5 倍と大きく異なっていたため、同時に評価した他の供試体がア ンカリング (anchoring and adjustment heuristic) 12)を引き起こ したことが示唆される。
Table 13 Evaluators $(N=200)$ and surrounding on cold joint survey

\begin{tabular}{lrrrrrr}
\hline & Min. & $25 \%$ & Med. & $75 \%$ & Max. & (Ave.) \\
\hline Evaluator age, years & 8 & 28 & 47.5 & 65 & 90 & $(47.1)$ \\
Evaluator gender & Female & $(102) ;$ Male $(98)$ & & & \\
Evaluator visual acuity & 0.03 & 0.8 & 1.0 & 1.2 & 2.0 & $(1.00)$ \\
Distance chosen by evaluator & $0.5 \mathrm{~m}$ & $(70) ; 1.0$ & $\mathrm{~m}$ & $(115) ;$ & $1.5 \mathrm{~m}(7) ;$ & $2.0 \mathrm{~m}(6) ;$ \\
Temperature, degree C & 17.5 & 18.5 & 19.3 & 20.3 & 23.9 & $(19.5)$ \\
Relative humidity & $32 \%$ & $48 \%$ & $49 \%$ & $53 \%$ & $61 \%$ & $(49.4 \%)$ \\
Illuminance, lx & 2300 & 3960 & 7350 & 8250 & 11700 & $(6222)$ \\
\hline
\end{tabular}

Table 14 Pearson's correlation coefficient / cold joint

\begin{tabular}{l|rrrr}
\hline & $\Delta L_{1}$ & $\Delta L_{2}$ & $\Delta L_{3}$ & $\Delta L_{4}$ \\
\hline "I'm bothered by the cold joint" & $.174^{* * *}$ & $.213^{* * *}$ & $.212^{* * *}$ & $.146^{* * *}$ \\
"aesthetically unacceptable" & $.155^{* * *}$ & $.175^{* * *}$ & $.182^{* * *}$ & $.143^{* * *}$ \\
"worrying from a structural standpoint" & $.117^{* * *}$ & $.133^{* * *}$ & $.138^{* * *}$ & $.100^{* * *}$ \\
\hline & & & & $* * *: p<.001$
\end{tabular}

Table 15 Result of logistic regression analysis / cold joint (1) Objective variable: "I'm not bothered by cold joint on the surface" $=0$, "I'm bothered" $=1$

\begin{tabular}{lrrrrr}
\multicolumn{1}{c}{ Explanatory variable } & $\begin{array}{r}\text { Regression } \\
\text { coefficient }\end{array}$ & \multicolumn{1}{c}{$p$} & Odds ratio & $95 \%$ lower & $95 \%$ upper \\
\hline Difference in lightness $\Delta \boldsymbol{L}_{3}$ & 0.459 & $<.001$ & $\mathbf{1 . 5 8 2}$ & 1.428 & 1.753 \\
Gender, female=0; male $=1$ & 0.719 & .001 & 2.052 & 1.355 & 3.108 \\
Evaluator age, years & 0.011 & .030 & 1.011 & 1.001 & 1.022 \\
Illuminance, klx & 0.120 & .003 & 1.128 & 1.040 & 1.222 \\
Constant & -6.953 & & & & \\
& & & & &
\end{tabular}

$p$ in $\chi^{2}$ test $<.001$

Table 16 Result of logistic regression analysis / cold joint (2) Objective variable: "aesthetically acceptable" $=0$, "unacceptable" $=1$

\begin{tabular}{lrrrrr}
\multicolumn{1}{c}{ Explanatory variable } & $\begin{array}{r}\text { Regression } \\
\text { coefficient }\end{array}$ & \multicolumn{1}{c}{$p$} & Odds ratio & 95\% lower & $95 \%$ upper \\
\hline Difference in lightness $\Delta \boldsymbol{L}_{3}$ & 0.493 & $<.001$ & $\mathbf{1 . 6 3 7}$ & 1.434 & 1.868 \\
Gender, female $=0$; male $=1$ & 0.956 & .001 & 2.602 & 1.498 & 4.520 \\
Constant & -6.519 & & & & \\
\hline
\end{tabular}

Table 17 Result of logistic regression analysis / cold joint (3) Objective variable: "not worrying from a structural standpoint" $=0$, "worrying" $=1$

\begin{tabular}{lrrrrr}
\multicolumn{1}{c}{ Explanatory variable } & $\begin{array}{r}\text { Regression } \\
\text { coefficient }\end{array}$ & \multicolumn{1}{c}{$p$} & Odds ratio & $95 \%$ lower & $95 \%$ upper \\
\hline Difference in lightness $\Delta L_{3}$ & 0.519 & $<.001$ & $\mathbf{1 . 6 8 0}$ & 1.393 & 2.027 \\
Gender, female $=0$; male=1 & 1.548 & .001 & 4.702 & 1.915 & 11.542 \\
Constant & -7.863 & & & & \\
\hline
\end{tabular}
$p$ in $\chi^{2}$ test $<.001$

\section{5. 実建築物に生じた不具合の感性評価}

\section{1 調査概要}

実建築物のコンクリートには、施工時の不具合に加えて経年に伴 う污れなどが同時に発生する。本章では、実建築物の打放しコンク リート部分に生じた複数の不具合を評価対象とした。アンケート調 査で観察対象とした実建築物は、2000 年 11 月竣工の北九州市立大 学ひびきのキャンパス事務棟、同大学特殊実験棟および北九州学術 研究都市体育館である。打放しコンクリート仕上げの壁および柱か ら、40 箇所（DB01〜40）の観察面を抽出した。ひとつの観察面は、 $700 \mathrm{~mm}$ x700 mm の枠で囲まれた範囲内とし、観察面の中心の高
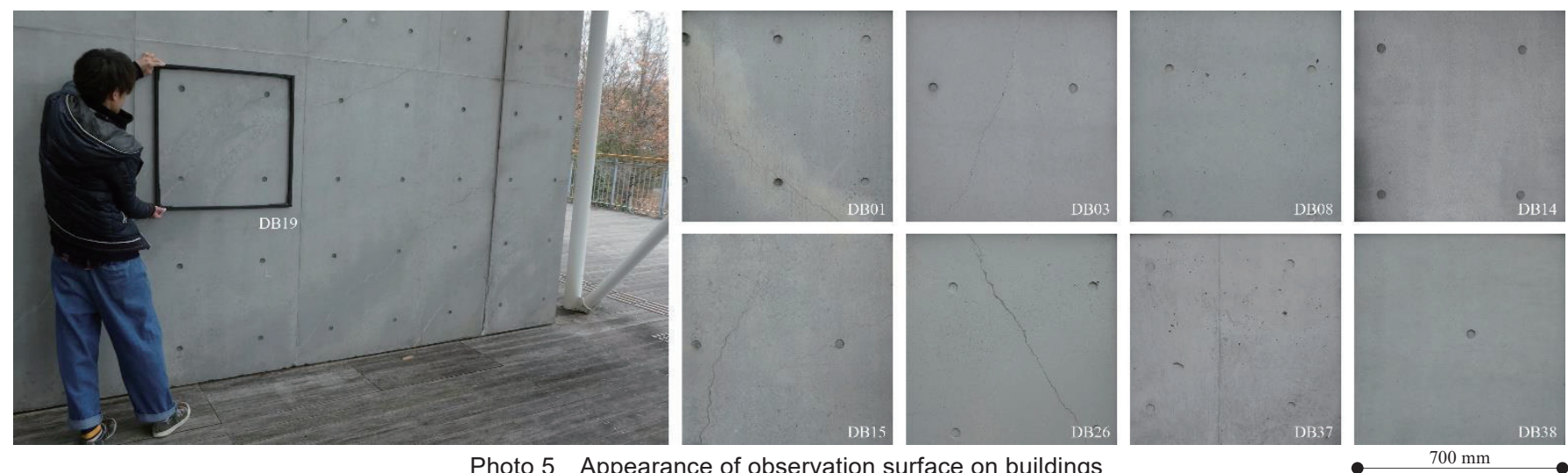

Photo 5 Appearance of observation surface on buildings 
Table 18 Characteristics of observation surface on building and results

\begin{tabular}{|c|c|c|c|c|c|c|c|c|c|c|c|c|c|c|c|c|c|c|c|c|c|}
\hline No. & DB01 & DB02 & DB03 & DB04 & DB05 & DB06 & DB07 & DB08 & DB09 & DB10 & DB11 & DB12 & DB13 & DB14 & DB15 & DB16 & DB17 & DB18 & DB19 & DB20 & \\
\hline Direction & $\mathrm{S}$ & $\mathrm{S}$ & $\mathrm{S}$ & $\mathrm{S}$ & E & E & E & E & E & E & $\mathrm{N}$ & E & E & $\mathrm{W}$ & $\mathrm{N}$ & $\mathrm{N}$ & $\mathrm{N}$ & E & E & E & \\
\hline Bug-hole area ratio & $0.375 \%$ & $0.333 \%$ & $0.187 \%$ & $0.411 \%$ & $0.342 \% 0$ & $0.444 \%$ & $0.556 \%$ & $1.303 \% 0$ & $0.151 \%$ & $0.540 \%$ & $0.395 \%$ & $0.148 \%$ & $0.152 \%$ & $0.099 \%$ & $0.284 \%$ & $0.338 \%$ & $0.166 \%$ & $0.136 \%$ & $0.744 \%$ & $0.485 \%$ & \\
\hline Crack width, mm & 0.338 & 0.380 & 0.439 & 0.283 & 0.290 & $\mathbf{0}$ & 0.200 & 0.060 & 0.410 & 0.104 & 0.211 & $\mathbf{0}$ & 0.135 & $\mathbf{0}$ & 0.367 & 0.270 & 0.356 & 0.250 & 0.335 & $\mathbf{0}$ & \\
\hline Chip on crack & $v$ & $v$ & & & $v$ & & $v$ & & $v$ & $v$ & & & & & & & & & $v$ & & \\
\hline Black stains in crack & & & & & & & & & & & & & & & $v$ & & $v$ & & & & \\
\hline Average of $\mathrm{L}^{*}$ & 75.47 & 75.48 & 75.02 & 74.80 & 71.84 & 75.44 & 75.47 & 71.87 & 73.20 & 74.61 & 72.77 & 74.42 & 73.68 & 64.92 & 68.40 & 69.98 & 69.31 & 70.46 & 69.29 & 70.15 & \\
\hline Average of $a^{*}$ & -0.01 & -0.50 & -0.17 & -0.20 & 0.37 & -0.30 & -0.29 & -0.52 & 0.52 & 0.62 & -0.12 & -0.17 & 0.21 & 0.02 & 0.01 & 0.01 & 0.26 & -0.30 & -0.21 & -0.33 & \\
\hline Average of $b^{*}$ & 6.10 & 3.82 & 3.97 & 3.84 & 5.73 & 3.74 & 3.84 & 3.26 & 5.64 & 6.24 & 3.84 & 4.64 & 5.43 & 4.38 & 4.59 & 4.63 & 5.64 & 4.23 & 4.05 & 4.00 & \\
\hline tandard deviation of $\mathrm{L}^{*}$ & 3.65 & 1.04 & 1.07 & 1.08 & 1.29 & 1.34 & 1.27 & 1.41 & 1.55 & 1.30 & 1.70 & 0.99 & 1.32 & 1.68 & 2.12 & 1.60 & 1.96 & 1.80 & 2.30 & 1.53 & \\
\hline Standard deviation of $\mathrm{b}^{*}$ & 1.97 & 0.43 & 0.47 & 0.46 & 0.69 & 0.54 & 0.51 & 0.68 & 0.66 & 0.61 & 0.55 & 0.85 & 0.46 & 0.64 & 1.22 & 0.75 & 0.96 & 0.54 & 0.61 & 0.89 & \\
\hline \multicolumn{22}{|l|}{ "I'm bothered by ..." } \\
\hline crack & $96 \%$ & $44 \%$ & $96 \%$ & $40 \%$ & $72 \%$ & $0 \%$ & $76 \%$ & $4 \%$ & $84 \%$ & $8 \%$ & $4 \%$ & $24 \%$ & $16 \%$ & $0 \%$ & $92 \%$ & $52 \%$ & $88 \%$ & $56 \%$ & $68 \%$ & $0 \%$ & \\
\hline bug-holes & $8 \%$ & $4 \%$ & $0 \%$ & $0 \%$ & $4 \%$ & $0 \%$ & $4 \%$ & $32 \%$ & $0 \%$ & $32 \%$ & $0 \%$ & $0 \%$ & $4 \%$ & $0 \%$ & $0 \%$ & $0 \%$ & $0 \%$ & $0 \%$ & $0 \%$ & $0 \%$ & \\
\hline mottling or staining & $72 \%$ & $8 \%$ & $8 \%$ & $8 \%$ & $48 \%$ & $16 \%$ & $32 \%$ & $24 \%$ & $16 \%$ & $12 \%$ & $64 \%$ & $12 \%$ & $36 \%$ & $48 \%$ & $52 \%$ & $56 \%$ & $44 \%$ & $20 \%$ & $88 \%$ & $60 \%$ & \\
\hline "Repair is necessary" & $84 \%$ & $0 \%$ & $28 \%$ & $0 \%$ & $16 \%$ & $0 \%$ & $12 \%$ & $4 \%$ & $12 \%$ & $0 \%$ & $4 \%$ & $4 \%$ & $4 \%$ & $0 \%$ & $64 \%$ & $8 \%$ & $48 \%$ & $0 \%$ & $56 \%$ & $0 \%$ & \\
\hline No. & DB21 & DB22 & DB23 & DB24 & DB25 & DB26 & DB27 & DB28 & DB29 & DB30 & DB31 & DB32 & DB33 & DB34 & DB35 & DB36 & DB37 & DB38 & DB39 & DB40 & ve.) \\
\hline Direction & E & E & W & E & W & E & $\mathrm{N}$ & E & E & E & E & E & W & W & W & $\mathrm{W}$ & $\mathrm{N}$ & E & E & $\mathrm{S}$ & \\
\hline Bug-hole area ratio & $0.521 \%$ & $0.338 \%$ & $0.558 \%$ & $0.226 \%$ & $0.270 \% 0$ & $0.456 \%$ & $0.448 \%$ & $0.216 \% 0$ & $0.443 \%$ & $0.223 \%$ & $0.229 \%$ & $0.288 \%$ & $0.236 \%$ & $0.361 \% 0$ & $0.349 \%$ & $0.657 \%$ & $0.539 \%$ & $0.361 \%$ & $0.217 \%$ & $0.138 \%$ & $(0.367 \%)$ \\
\hline Chip on crack & & & & $v$ & & $v$ & & & & & & & & & & $v$ & & & & & \\
\hline Black stains in crack & & & & & & $v$ & & & & & & $v$ & & & & & & & & & \\
\hline Average of $L^{*}$ & 69.62 & 67.94 & 77.30 & 74.02 & 74.15 & 71.09 & 74.99 & 74.12 & 73.23 & 73.42 & 72.95 & 72.29 & 74.43 & 73.83 & 72.16 & 71.67 & 71.41 & 73.70 & 74.22 & 66.82 & $(72.50)$ \\
\hline Average of $a^{*}$ & -0.16 & -0.38 & 0.20 & 0.39 & -0.10 & -0.18 & -0.34 & 0.45 & 0.68 & 0.71 & 0.76 & 0.06 & 0.34 & 0.28 & 0.29 & 0.43 & 0.07 & -0.80 & -0.80 & -0.23 & $(0.01)$ \\
\hline Average of $b^{*}$ & 4.52 & 3.61 & 5.97 & 5.33 & 5.82 & 3.56 & 7.37 & 6.07 & 6.31 & 6.31 & 6.77 & 5.59 & 6.11 & 5.63 & 5.76 & 6.54 & 4.77 & 3.01 & 3.48 & 4.53 & $(4.97)$ \\
\hline Standard deviation of $\mathrm{L}^{*}$ & 1.71 & 1.85 & 1.5 & 1.39 & 1.4 & 0.63 & 2.49 & 2.05 & 1.49 & 1.45 & 1.84 & 1.60 & 1.73 & 1.62 & 2.78 & 1.41 & 1.49 & 1.47 & 1.38 & 2.43 & (1.65) \\
\hline Standard deviation & 0.18 & 0.13 & 0.19 & 0.11 & 0.10 & 0.14 & 0.25 & 0.18 & 0.18 & 0.17 & 0.22 & 0.24 & 0.31 & 0.27 & 0.36 & 0.29 & 0.08 & 0.11 & 0.09 & 0.31 & $(0.18)$ \\
\hline Standard & 0.79 & 0.58 & 0.78 & 0.43 & 0.59 & 0.46 & 1.28 & 0.61 & 0.60 & 0.47 & 0.64 & 1.06 & 0.90 & 0.78 & 1.09 & 0.99 & 0.44 & 0.52 & 0.52 & 0.84 & $(0.72)$ \\
\hline $\begin{array}{l}\text { "I'm bothered by ..." } \\
\text { crack }\end{array}$ & $8 \%$ & $4 \%$ & $64 \%$ & $32 \%$ & $12 \%$ & $92 \%$ & $0 \%$ & $0 \%$ & $0 \%$ & $44 \%$ & $16 \%$ & $92 \%$ & $92 \%$ & $0 \%$ & $92 \%$ & $84 \%$ & $4 \%$ & $0 \%$ & $4 \%$ & $88 \%$ & $(41 \%)$ \\
\hline bug-holes & $8 \%$ & $0 \%$ & $24 \%$ & $12 \%$ & $12 \%$ & $8 \%$ & $12 \%$ & $0 \%$ & $20 \%$ & $0 \%$ & $0 \%$ & $0 \%$ & $16 \%$ & $12 \%$ & $4 \%$ & $20 \%$ & $36 \%$ & $0 \%$ & $12 \%$ & $0 \%$ & $(7 \%)$ \\
\hline mottling or staining & $48 \%$ & $36 \%$ & $32 \%$ & $20 \%$ & $16 \%$ & $4 \%$ & $88 \%$ & $56 \%$ & $40 \%$ & $52 \%$ & $36 \%$ & $72 \%$ & $40 \%$ & $40 \%$ & $40 \%$ & $28 \%$ & $48 \%$ & $12 \%$ & $8 \%$ & $48 \%$ & $(37 \%)$ \\
\hline "Repair is necessary" & $0 \%$ & $0 \%$ & $12 \%$ & $0 \%$ & $0 \%$ & $72 \%$ & $8 \%$ & $0 \%$ & $0 \%$ & $4 \%$ & $0 \%$ & $76 \%$ & $40 \%$ & $0 \%$ & $32 \%$ & $12 \%$ & $12 \%$ & $0 \%$ & $0 \%$ & $40 \%$ & $(16 \%)$ \\
\hline
\end{tabular}

さは基本的に約 $1.5 \mathrm{~m}$ とした。 40 のうち 5 箇所の観察面は、直射日 光が当たる南向きとした。観察面の一部をPhoto 5 に、各観察面で 測定された特性值を Table 18 に示す。観察面の DB01 および DB19 には、ひび割れを伴う明瞭な打重ね線が生じていた。

実建築物を対象としたアンケート調査では、被験者 (25 名)に 40 箇所の観察面を順番に観察してもらった。ひとつの観察面につき「ひ び割れ」、「色むら」、「污れ」および「その他」から気になる事象（複 数可)があれば指摘してもらった注 ${ }^{14)}$ 「との他」が指摘された場合、 具体的に何が気になったのかを都度ヒアリングした。その後、観察 面に対して「補修の必要がある一必要がない」の質問に対して 2 段 階評価で回答してもらった。

アンケート調查の期間は 2020 年 1 月 13 日〜 17 日とした。調査 時の天候は晴れもしくは量りであった。被験者（25 名）の属性およ びアンケート実施時の気象情報の分布を Table 19 に示す。被験者は 観察対象とした建物の利用者から募集した。観察距離は被験者に指 定せず、被験者から問われれば「好みの位置で観察してください」 とだけ返答した。

\section{2 調査結果、分析および考察}

気になる事象として指摘された不具合を目的変数、観察面の特性 值、被験者属性および気象情報を説明変数とした重回帰分析の結果 をTable 20 に示す。得られた標準偏回帰係数汃ら、被験者に気に なる事象として表面気泡を指摘させる最大の因子が表面気泡面積比、 ひび割れを指摘させる最大の因子がひび割れ幅、色むらもしくは污 れを指摘させる最大の因子が明度 $\mathrm{L}^{*}$ の標準偏差であると考察され る。次に、目的変数に対して最も大きい標準偏回帰係数 $\beta$ を示した因 子のみを説明変数として投入した二項ロジスティック回帰分析を実 施した。分析結果を Table 21２3 に示す。全ての分析結果において モデル $\chi^{2}$ 検定の結果は $p<.001$ で有意であった。得られた偏回帰係
Table 19 Evaluator $(N=25)$ and surrounding / buildings

\begin{tabular}{lrrrrrr}
\hline & Min. & $25 \%$ & Med. & $75 \%$ & Max. & (Ave.) \\
\hline Evaluator age, years & 20 & 24 & 40 & 57 & 68 & $(40.4)$ \\
Evaluator gender & Female $(12) ;$ Male (13) & & & \\
Evaluator visual acuity & 0.6 & 0.8 & 1.0 & 1.2 & 2.0 & $(1.08)$ \\
Temperature, degree C & 9.1 & 9.3 & 9.4 & 9.5 & 11.6 & $(9.5)$ \\
Relative humidity & $45 \%$ & $47 \%$ & $56 \%$ & $59 \%$ & $65 \%$ & $(54.2 \%)$ \\
Illuminance, lx & 61 & 1760 & 3210 & 6510 & 59900 & $(5264)$ \\
\hline
\end{tabular}

Table 20 Standardized partial regression coefficient $\beta$

\begin{tabular}{lccc}
\hline \multicolumn{1}{c}{ Explanatory variable } & \multicolumn{2}{c}{ Objective variable: "not bothersome" $=0$, "bothersome" $=1$} \\
& Bug-holes & Crack & Mottling or Staining \\
\hline Bug-hole area ratio & $.238^{* * *}$ & $.104^{* *}$ & $.085^{*}$ \\
Crack width, without $=0$; with $=1$ & -.070 & $.547^{* * *}$ & -.002 \\
Chip on crack, without $=0$; with=1 & .012 & $.067^{*}$ & -.033 \\
Black stains in crack & .001 & .026 & -.011 \\
Average of L* & .025 & -.043 & $-.123^{* *}$ \\
Average of a* & -.022 & .004 & .049 \\
Average of b* & $.195^{* *}$ & $-.164^{* *}$ & .099 \\
Standard deviation of $\mathrm{L}^{*}$ & -.061 & $-.111^{*}$ & $.278^{* * *}$ \\
Standard deviation of $\mathrm{a}^{*}$ & .020 & $.140^{* *}$ & $-.203^{* *}$ \\
Standard deviation of $\mathrm{b}^{*}$ & -.049 & $.204^{* * *}$ & .129 \\
Gender, female=0; male $=1$ & $.088^{* *}$ & -.030 & $.142^{* * *}$ \\
Evaluator age & .002 & -.062 & .019 \\
Visual acuity & $.101^{* *}$ & $-.064^{*}$ & -.013 \\
Temperature & $.104^{* * *}$ & .011 & $-.126^{* * *}$ \\
Relative humidity & $-.233^{* * *}$ & $.100^{* *}$ & -.070 \\
Illuminance & .008 & .013 & -.033 \\
\hline \multicolumn{1}{c}{$R^{2}$} & .137 & .488 & .149 \\
\hline & & $* p<.05, * *: p<.01, * * *: p<.001$
\end{tabular}

Table 21 Result of logistic regression analysis / buildings (1) Objective variable: "I'm not bothered by bug-holes" $=0$, "I'm bothered" $=1$

\begin{tabular}{lrrrrr}
\hline Explanatory variable & $\begin{array}{r}\text { Regression } \\
\text { coefficient }\end{array}$ & $p$ & Odds ratio & $95 \%$ lower & $95 \%$ upper \\
\hline Bug-hole area ratio, \% & 2.606 & $<.001$ & $\mathbf{1 3 . 5 4 6}$ & 6.089 & 30.137 \\
Constant & -3.686 & & & & $p$ in $\chi^{2}$ test $<.001$
\end{tabular}

Table 22 Result of logistic regression analysis / buildings (2) Objective variable: "I'm not bothered by crack" $=0$, "I'm bothered" $=1$

\begin{tabular}{lrcrrr}
\hline Explanatory variable & $\begin{array}{r}\text { Regression } \\
\text { coefficient }\end{array}$ & $p$ & Odds ratio & $95 \%$ lower & $95 \%$ upper \\
\hline Crack width, $\mathbf{0 . 1} \mathbf{~ m m}$ & 1.434 & $<.001$ & $\mathbf{4 . 1 9 5}$ & 3.508 & 5.017 \\
Constant & -3.661 & \multicolumn{5}{c}{} \\
\hline
\end{tabular}


数から、被験者の $50 \%$ が不具合を気にしないときの表面気泡面積比 の限界は $1.30 \%$ 超、ひび割れ幅の限界は $0.26 \mathrm{~mm}$ 、明度 $\mathrm{L}^{*}$ の標準 偏差の限界は 2.1 と推定される。また、0.3 mm のひび割れ幅 ${ }^{11)}$ 被験者の $65 \%$ が気にすることが推定される。これらの限界は、供試 体を評価対象とした調查で得られたもの（第 2,3 章）より寛大であ る。実建築物に生じた不具合に対する評価が、供試体に生じたもの より単に寛大であることが示唆されるものの、被験者に対する質問 方法が異なっていたこと、被験者にとって見慣れた対象に生じた不 具合であったことが寬大な評価に繋がった可能性も考えられる。

気になる事象として指摘された不具合同士の相関を Table 24 に 示す。表面気泡、ひび割れおよび色むら・污れの指摘の間に相関関 係は認められなかった。3つの不具合に対する被験者の指摘はほぼ 独立していた。そのうえで、実建築物のコンクリートに生じた表面 気泡、ひび割れおよび色むら・污れが気になるか否が、補修の要否 の判断に与える影響を共分散構造分析によって検討した。「補修の必 要がある」を正、「必要がない」を負とし、得られた補修の要否の判 断モデルを Fig. 5 に示す。ひび割れおよび色むら・污れの評価から 補修の判断への有意なパスが認められた。更に、標準化パス係数の 大きさから、ひび割れの評価の方が、色むら・污れより補修の判断 に与える影響が大きいことが示唆される。一方、表面気泡の評価か ら補修の判断への有意なパスは認められなかった。表面気泡は気に なったとしても補修の必要がない、もしくは補修できない不具合と いう認識が一般的なようである。

補修の要否の判断を目的変数とした二項ロジスティック回帰分析 を実施した。前述の分析結果から、説明変数にはひび割れ幅および 明度 $\mathrm{L}$ *の標準偏差のみを投入した。分析結果を Table 25 に示す。 モデル $\chi^{2}$ 検定の結果は $p<.001$ で有意であり、ひび割れ幅および明 度 $\mathrm{L}^{*}$ の標準偏差は共に有意 $(p<.05)$ な説明変数であった。得られ た偏回帰係数から、被験者の $50 \%$ が「補修の必要がない」と回答す るひび割れ幅の限界は、色むら・污れが少ないコンクリート（明度 $\mathrm{L}^{*}$ の標準偏差 $=0.6$ : 今回の観察面の最小）において $0.44 \mathrm{~mm}$ を超 え、0.3 $\mathrm{mm}$ のひび割れ幅 ${ }^{11)}$ に対して被験者の $9 \%$ が補修を求める (91\%が補修を求めない) ことが推定される。一方、ひび割れが無 い場合、明度 $\mathrm{L}^{*}$ の標準偏差が 3.7 (今回の観察面の最大) のコンク リートに対して、被験者の $8 \%$ が補修を求める $(92 \%$ が補修を求めな い)ことが推定される。

\section{6. まとめ}

本論文では、コンクリート供試体および鉄筋コンクリート建物に 生じた不具合の外観を評価するアンケート調查を実施し、調查結果 を主に二項ロジスティック回帰で分析した。その結果、以下の知見 が得られた。

1)コンクリート供試体に生じた表面気泡の感性評価に対し、表面気 泡面積比および被験者の性別が比較的強く影響することが認めら れた。被験者の $50 \%$ が供試体の表面気泡を気にしない表面気泡面 積比の限界は、女性の場合 $0.30 \%$ 、男性の場合 $0.53 \%$ と推定され た。同様に、被験者の $50 \%$ が表面気泡を美観的に許容できる/構 造的に不安を感じない表面気泡面積比の限界は、被験者が女性の 場合 $0.44 \% / 0.85 \%$ 、男性の場合 $0.69 \% / 1.22 \%$ と推定された。 2) コンクリート供試体に導入されたひび割れの感性評価に対し、ひ
Table 23 Result of logistic regression analysis / buildings (3) Objective variable: "I'm not bothered by mottling or staining" $=0$, "I' $\mathrm{m}$ bothered" $=1$

\begin{tabular}{lrcrrr}
\multicolumn{1}{|c}{ Explanatory variable } & $\begin{array}{r}\text { Regression } \\
\text { coefficient }\end{array}$ & $p$ & Odds ratio & $95 \%$ lower & $95 \%$ upper \\
\hline Standard deviation of $\mathbf{L}^{*}$ & 1.288 & $<.001$ & $\mathbf{3 . 6 2 5}$ & 2.708 & 4.852 \\
Constant & -2.666 & & & & \\
\hline
\end{tabular}

$p$ in $\chi^{2}$ test $<.001$, Percentage correct $=67.2$

Table 24 Pearson's correlation coefficient / buildings

\begin{tabular}{l|ccc}
\hline & Bug-holes & Crack & Mottling or Staining \\
\hline Bug-holes & 1 & -.034 & .012 \\
Crack & & 1 & -.044 \\
Mottling or Staining & & & 1 \\
\hline
\end{tabular}

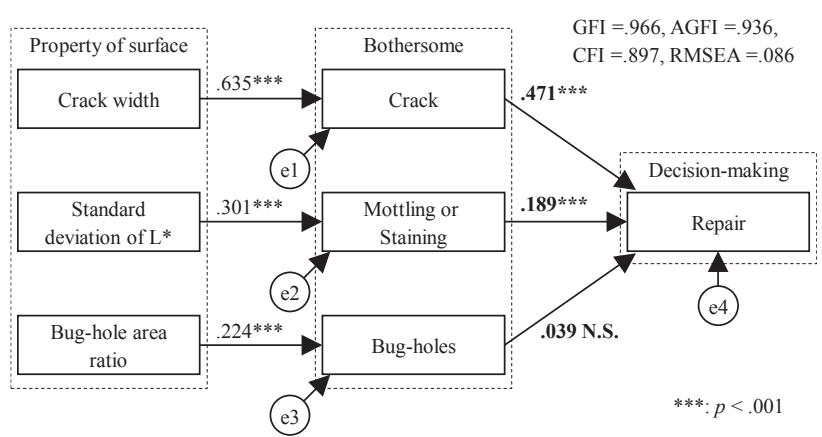

Fig.5 A modele of decision-making for repair of defects

Table 25 Result of logistic regression analysis / buildings (4) Objective variable: "repair is unnecessary" $=0$, "repair is necessary" $=1$

Explanatory variable

Crack width, $0.1 \mathrm{~mm}$ Standard deviation of $\mathrm{L}^{*}$

Constant

\begin{tabular}{rcrrr}
$\begin{array}{r}\text { Regression } \\
\text { coefficient }\end{array}$ & \multicolumn{1}{c}{$p$} & Odds ratio & $95 \%$ lower & $95 \%$ upper \\
\hline 0.995 & $<.001$ & $\mathbf{2 . 7 0 4}$ & 2.200 & 3.324 \\
0.937 & $<.001$ & $\mathbf{2 . 5 5 2}$ & 1.906 & 3.418 \\
-5.857 & \multicolumn{4}{c}{$p$ in $\chi^{2}$ test $<.001$, Percentage correct $=85.4$}
\end{tabular}

び割れ幅および観察距離が比較的強く影響することが認められた 供試体が $1.6 \mathrm{~m}$ 離れた位置から観察されたとき、 $0.3 \mathrm{~mm}$ のひび 割れ幅を被験者の $92 \%$ が気にし、 $82 \%$ が美観的に許容できず、 $80 \%$ が構造的に不安を感じることが推定された。

3)供試体に生じたコールドジョイントの外観は、打重ね時間間隔を 最大 3 時間としても、他の不具合と比較して注目され難かった。 観察面で測定された明度 L*の差が大きいほどコールドジョイン 卜の外観に対する被験者の回答が厳しかった。一方、表面気泡お よびひび割れの評価と逆に、女性より男性の方がコールドジョイ ントの外観に厳しい評価をする傾向が認められた。

4) 実建築物のコンクリートに生じた不具合を観察した場合、被験者 の $50 \%$ が表面気泡を気にしない表面気泡面積比の限界は $1.30 \%$ 超、色むらもしくは污れを気にしない明度 $\mathrm{L}^{*}$ の標準偏差の限界は 2.1 と推定された。また、実建築物のコンクリートに生じた 0.3 $\mathrm{mm}$ のひび割れ幅に対し、被験者の $65 \%$ が気にするものの、 $91 \%$ が補修を求めないこと（色むら・污れが少ない場合）が推定され た。実建築物に生じた不具合に対する感性評価は、供試体に生じ たものより総じて寛大であった。

5) 以上の外観の限界を検討したアンケート調査において、同時に評 価した別の観察面の不具合によるアンカリングや、被験者に対す る質問方法の影響、被験者にとって見慣れた対象に生じた不具合 であったことの影響が評価に作用した可能性が考察された。

\section{謝辞}

本研究は JSPS 科研費 $18 \mathrm{~K} 13872$ の助成を受けたものです。 
1) Okajima, T., Kawabe, S., Mizoguchi, Y. and Kuno, M.: Visual assessment of surface finishing concrete, Cement Research and Technology, Vol.5, No.2, pp.95-102, 1994.7 (in Japanese)

岡島達雄, 河辺伸二, 溝口雄一, 久野雅士: コンクリート素地仕上げの視 覚心理学的評価, コンクリート工学論文集, 第 5 巻, 第 2 号, pp.95-102, 1994.7

2) Liu, L., Masuda, Y., Konishi, T. and Sakaki, T.: Sensibility evaluation to colored architectural concrete using color sand and pigments, Journal of Structural and Construction Engineering (Transactions of AIJ), Vol.73, No.630, pp.1233-1238, 2008.8 (in Japanese) 劉霊芝, 桝田桂宽, 小西敏正, 榊智也: 着色細骨材および顔料を用いた打 放しコンクリートの色彩に対する感性評価に関する研究, 日本建築学会 構造系論文集, 第 73 巻, 第 630 号, pp.1233-1238, 2008.8

3) Nakayama, D., Takasu, K., Suyama, H. and Koyamada, H.: Impression evaluation of concrete surface using byproducts, The Fourth Australasia and South-East Asia Structural Engineering and Construction Conference (ASEA SEC 4), Brisbane, Australia, MAT-20$1 \sim 6,2018.12$

4) American Concrete Institute (AIC): ACI 309.1R-08 Report on Behavior of Fresh Concrete During Vibration, 2008.8

5) Architectural Institute of Japan (AIJ): JASS 5 Reinforced Concrete Work, 2018.7 (in Japanese)

日本建築学会：建築工事標準仕様書・同解説 JASS 5 鉄筋コンクリート工 事, 2018.7

6) Haldane, D.: The importance of cracking in reinforced concrete members, Performance of Building Structures, Proceedings of the International Conference held at Glasgow University, pp.99-109, 1976

7) Fédération internationale du béton (fib): Structural Concrete Textbook on behaviour, design and performance, Second edition Volume3 "Design of durable concrete structures", Bulletin No.53, 2009.12

8) Campbell-Allen, D.: The reduction of cracking concrete, University of Sydney and Cement and Concrete Association of Australia, 1979.5

9) European Committee for Standardization (CEN): Eurocode 2 "Design of concrete structures", 2004.12

10)Hall, E.T.: The Hidden Dimension, the United States, Anchor, 1966

11) AIJ: Recommendations for Practice of Crack Control in Reinforced Concrete Buildings (Design and Construction), 2006.2 (in Japanese) 日本建築学会：鉄筋コンクリート造建築物の収縮ひび割れ制御設計・施工 指針（案）・同解説, 2006.2

12) Tversky, A. and Kahneman, D.: Judgment under Uncertainty: Heuristics and Biases, Science, Vol.185, Issue4157, pp.1124-1131, 1974.9

注

注 1）ロジスティック回帰（David Cox 1958）とは、Bernoulli 分布に従う 変数の統計的回帰モデルである。目的変数が原則的に 2 值データでな ければならない制約があるものの、説明変数が正規分布であること求 められない点や得られるオッズ比の解釈が容易な点などの利点が多く、 公衆衛生やマーケティングの分野で広く利用されている分析手法であ る。ロジスティック回帰では、目的変数の確率 $P$ と説明変数 $x_{1}, x_{2} \cdots$ と の間に、偏回帰係数 $\beta_{0}, \beta_{1}, \beta_{2} \cdots$ を用いた次式の関係を想定する。

$P=\frac{1}{1+\exp \left(-\left(\beta_{0}+\beta_{1} x_{1}+\beta_{2} x_{2}+\cdots\right)\right)}$

注 2）ビーム角度を優先して光源を選定した。

注 3） 画像の 2 段調化およびピクセル数のカウントには Adobe Photoshop CC 2018 を用いた。

注 4）明度 $\mathrm{L}$ *および色度 $\mathrm{a}$ *, b*（JIS Z 8729／CIE1976 L*a*b*色空間に準 拠）の測定には MINOLTA 社製 CM-700d を用い、正反射除去 (SCE) の值を採用した。

注 5）供試体を傾けて展示した理由は、強風による転倒防止を目的とした安 全のためである。観察し易さに配慮して $10^{\circ}$ の俯角を採用した。

注 6） Hall の研究 10)に基づいて水平視角 $12^{\circ}$ の領域を明瞭な視覚とした場 合、 $1.5 \mathrm{~m}$ の距離で被験者は明瞭な視覚の領域に供試体の観察面のほ ぼ全てを丁度収めることになる。

注 7）本論文では、二項ロジスティック回帰分析をはじめとする全ての統計
分析に IBM SPSS Statistics 26 およびAmos 26 を用いた。

注 8）推定にあたり、表面気泡面積比および被験者の性別を除く有意な説明 変数には調査時の平均を代入した。

注 9） Fig. 1 の条件で撮影した写真を加工した。

注 10） 40 体の供試体を作成した後、同じような見た目のひび割れが生じた供 試体や、ひび割れを除く不具合が著しい供試体を割愛し、アンケート 調査に用いる 10 体の供試体を選抜した。

注 11）推定にあたり、ひび割れ幅および観察距離を除く有意な説明変数には 調査時の平均を代入した。

注 12）色度 $\mathrm{a}^{*}, \mathrm{~b}$ *については変動が小さく、目視による認知も困難だったた め、変動が大きい明度 $\mathrm{L}^{*}$ のみを評価に用いた。

注 13）説明変数に表面気泡面積比のみを投入して推定した。

注 14）その他を除く 3 項目は、事前に 5 名の被験者で予備実験を行った際に 指摘が多かった上位 3 項目である。 


\title{
A CONSIDERATION ON ACCEPTABLE LIMITS OF APPEARANCE OF BUG-HOLES, CRACKS, COLD JOINTS AND STAINING ON EXPOSED CONCRETE
}

\author{
Hiroki SUYAMA ${ }^{* 1}$, Koji TAKASU $^{* 2}$ and Hidehiro KOYAMADA ${ }^{* 2}$ \\ *1 Assoc. Prof., Dept. of Architecture, Faculty of Environmental Engineering, The Univ. of Kitakyushu, Dr.Eng. \\ * ${ }^{2}$ Prof., Dept. of Architecture, Faculty of Environmental Engineering, The Univ. of Kitakyushu, Dr.Eng.
}

\begin{abstract}
Most previous studies on the appearance of concrete rely on rules of thumb developed in the field and are limited to qualitative descriptions. Accordingly, except for crack width, there are few quantitative management standards for the appearance of exposed concrete. In this study, we conducted several questionnaire surveys of different types involving the evaluation of surface defects in concrete specimens and reinforced concrete buildings. We investigated the acceptability of visual concrete defects by quantifying the influence of various factors on psychological evaluations of concrete appearance through binomial logistic regression analysis. The investigation yielded the following findings.
\end{abstract}

For concrete specimens, sensory evaluations of bug-holes were influenced by the bug-hole area ratio and gender of the evaluator. Limits of the bug-hole area ratio at which half of evaluators are expected to respond "I'm not bothered by the air bubbles on the surface" were estimated to be $0.30 \%$ for women and $0.53 \%$ for men. Similarly, limits of the bug-hole area ratio at which half of evaluators are expected to respond "the appearance is aesthetically unacceptable" and "I'm not worried from a structural standpoint" were estimated as $0.44 \%$ and $0.85 \%$ for women and $0.69 \%$ and $1.22 \%$ for men, respectively.

Sensory evaluations of cracks in concrete specimens were influenced by crack width and viewing distance. At a viewing distance of $1.6 \mathrm{~m}$, a crack width of $0.3 \mathrm{~mm}$, which is generally used as the threshold for determining the risk of degradation, is expected to be evaluated as bothersome by $92 \%$ of evaluators, aesthetically unacceptable by $82 \%$ of evaluators, and structurally worrisome by $80 \%$ of evaluators.

Cold joint appearance tended to be noticed less frequently by evaluators compared with other defects, even when the time interval between placements was 3 hours. Evaluators' negative evaluations of cold joints increased as the difference in surface lightness increased. Whereas female evaluators tended to respond more negatively to bug-holes and cracks than their male counterparts, male evaluators tended to respond more negatively to cold joint appearance than their female counterparts.

For the concrete of actual buildings, the limit of the bug-hole area ratio at which half of evaluators are expected to respond "I'm not bothered by bug holes" was estimated to exceed $1.30 \%$, and the limit of the standard deviation in lightness at which half of evaluators are expected to respond "I'm not bothered by mottling or staining" was estimated as 2.07. Furthermore, it was estimated that a crack width of $0.3 \mathrm{~mm}$ would be evaluated as bothersome by $65 \%$ of evaluators and as requiring repair by $9 \%$ of evaluators (and as not requiring repair by $91 \%$ ). Evaluations of defects in actual buildings were more positive than evaluations of defects in specimens.

Evaluators' responses regarding acceptable appearance may have been influenced by an anchoring and adjustment heuristic based on the defects of other surfaces that were viewed at the same time, the manner of questioning, and the familiarity of the object with defects to the evaluators.

(2021 年 8 月 3 日原稿受理, 2021 年 10 月 28 日採用決定) 